\title{
CONFLICT AND RECONCILIATION IN PRIGORODNY REGION
}

The Prigorodny conflict is one among many other ethnic disputes held in the Caucasus region after the dismantling of the Soviet Union. Even though the conflict itself could be classified as a small-scale clash, the outcomes have had an immense impact on the overall dynamics of the regional development. The outburst of the conflict was in the early 90s. The armed confrontation among the Ossetians and the Ingush was accompanied by the passive involvement of the Russian Federation. Almost three decades have passed since the formal ceasefire. However, the people still struggle to reach a settlement for peaceful cohabitation. The reasons for this partial deadlock are political and cultural. From the political perspective, the Russian Federation plays a crucial role. While being a recognized negotiator between the conflicting parties, Moscow has remained a supporter of the Ossetian side. This condition has been a real obstacle in the peace talks. The Ingush felt that they were left alone on the negotiating table. The cultural obstacles of the reconciliation largely derive from the religious and ethnic identification of the people. If the religious factors (Orthodox Ossetians versus Muslim Ingush) come from the Tsarist Russia, the ethnic identification is a product of the Soviet policies, which labeled the nations as reliable or unreliable (Sokirianskaia, 2005/2006: 6).

This article tries to present a concise overview of the three-stages of relations among the Ossetians and the Ingush: (1) pre-conflict, (2) conflict and (3) post-conflict. The text starts with a retrospective analysis of political and cultural disposition of the peoples (1). The research shows that the main determinant of the status of the ethnic groups was not self-referential, neither was it established in a regional context. The evidence suggests that the faith of the people was determined according to their level of devotion to Russia. ${ }^{1}$ In this respect, the Ossetians have always enjoyed their special role (the stronghold of Russia), while the Ingush have had to go through the periods of severe repressions and political injustices. The Prigorodny Conflict was an outcome of the long lasting preferential treatment of the people under the Soviet rule and the inability of the early post-Soviet Russia to establish the rights based on peace in the region. The work precedes with the conflict details (2). This is important not only for a descriptive purpose, but also to show the creation of the discourses that have dominated in the post-conflict relations. Finally, the text analyses the process of reconciliation (3). The article examines the scale and

\footnotetext{
1 The Russian Empire, the USSR and the Russian Federation.
} 
effectiveness of intergovernmental agreements by analyzing the relations between the Ossetian, Ingushetian and Russian authorities. The research proposes a general set of political factors that have been shaping the societal attitudes of the conflicting parties. The work is particularly interested in finding some key reasons which determined the Kremlin's position(s) in the conflict and reconciliation.

\section{HISTORICAL ORIGIN OF PRIGORODNYCONFLICT}

The outburst of the armed violence over the Prigorodny region among the North Ossetian and Ingush ethnic groups sparked in October-November of 1992. However, the historical roots of the clash can be traced all the way back to Tsarist Russia.

The empires treated the Ingush and the North Ossetian people differently. The Ingush are a family of an indigenous Northern Caucasian ethnic group known as Vainakh (Sunni Muslims). This group has a well-known record of disobedience toward Tsarist Russia. In contrast, the mostly Christian Ossetians have been allies of Russia for centuries. After the USSR was established, the regular order of things had changed. However, structural transformation does not always involve a shift in attitudes.

In 1920, Soviet Russia created the Mountain Autonomous Soviet Socialist Republic that included Ingush, Ossetians, Chechens, Kabards, Karachai, Cherkess, and Balkars. The republic was short-lived and by a decree of the All-Union Central Executive Committee, it was disintegrated into different autonomous regions. As a result, in 1924, the Ingush Autonomous Oblast was created. Vladikavkaz became an administrative center (autonomous unit) for the Sunzha Cossack District, North Ossetia and Ingushetia. The Prigorodny region in this setting was a part of Ingushetia.

In the 1930s, the Soviet policy of relatively great autonomy of the national minorities was replaced with the ethnic integration policy and the talks on the unification of the Chechens and Ingush started (Albogachieva, 2012: 45). Shortly thereafter, in 1936, Chechen and Ingush people were merged in the Chechen-Ingush ASSR with a capital Grozny. This merger caused a major administrative shift, as Vladikavkaz became an exclusively North Ossetian center.

11,000 Ingush joined the Soviet army in the Great Patriotic War (WW2); 4,000 have been killed and 46 had received the orders of the Hero of the Soviet Union (Albogachieva, 2012: 45). The Communist party did not appreciate the wartime achievements of the Vainakhs properly. Chechens and Ingush were accused of treachery and deported from the homeland to Central Asia in 1944. During the first year in exile, approximately 30-50 percent of the deported population had died of hunger and cold (Telegraph, 2001).

The administrative continuation of the events was a decree dissolving the ChechenIngush ASSR. Subsequently the Prigorodny District became a part of North Ossetia and around 30,000 ethnic Ossetians were placed in the houses of the deported Ingush. It is important to underline that the number of those re-settlers were forced to move to the new place (the refusal to go could entail administrative repressions); however, the dominant narratives in Ingushetia put all the blame on the Ossetians (Sokirianskaia, 2005/2006: 7). 


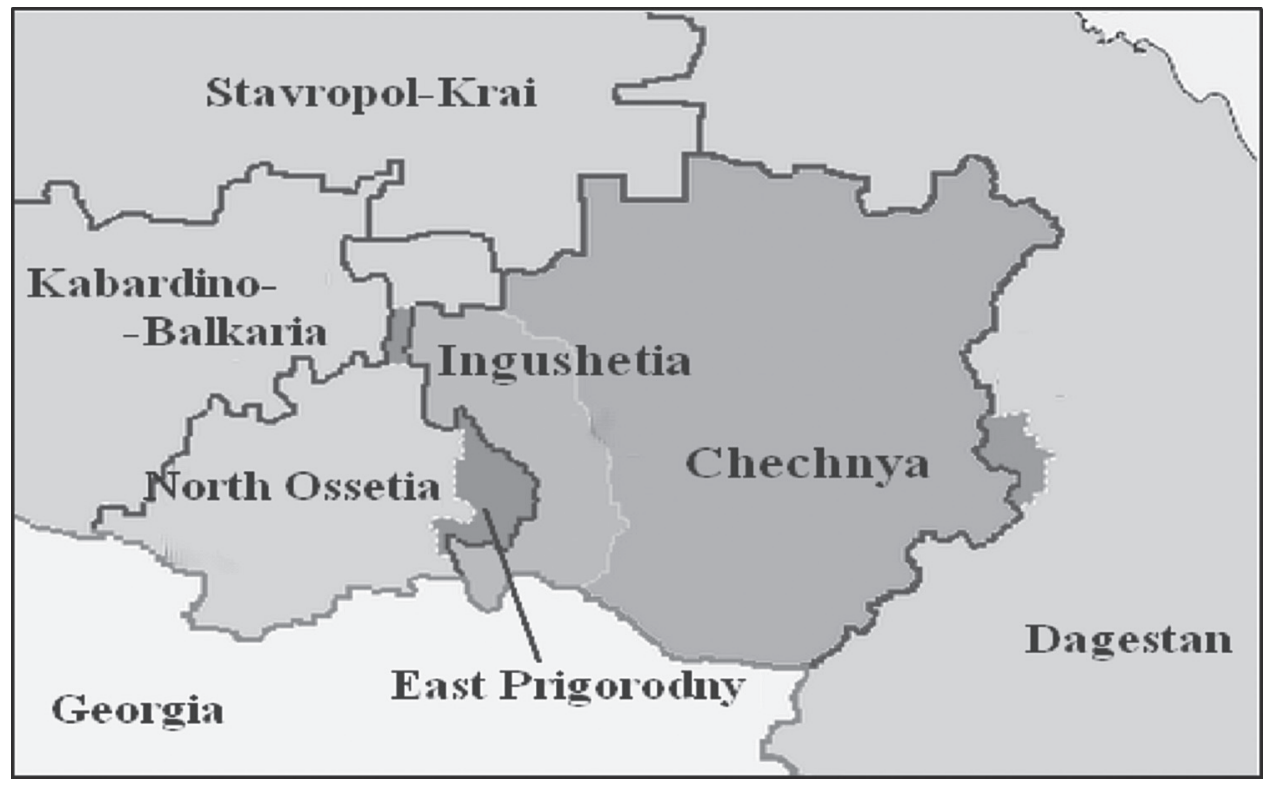

Source: https://northcaucasusland.wordpress.com (21.01.2017).

After Stalin's death, Nikita Khrushchev initiated the rehabilitation policy and consequently, ${ }^{2}$ on November 24, 1956, the Soviet government adopted the Decrees on the Restoration of the National Autonomy of the Kalmyk, Balkar, Chechen, Ingush and Karachai peoples and the Decree on the Restoration of the Chechen-Ingush ASSR as Part of the Russian Soviet Federative Socialist Republic - RSFSR (Pokalova, 2015: 17). The decrees included a four-year plan of return of the Vainakhs. On January, 9, 1957, the Chechen-Ingush ASSR was re-established. The Ingush population expected the restoration of the borders to the pre-deportation status quo, but the Soviet officials had different plans. The Prigorodny region stayed within the boundaries of North Ossetia and as compensation, the Chechen-Ingush ASSR received the Cossack areas - the Naurskii and Shelkovskii regions (Pokalova, 2015: 17).

The Ingush did not give up hopes on returning to Prigorodny. In the 1970-80s, the relations between the Ossetians and Ingush populations became tense. The tension was largely inspired by speeches and publications of the intellectuals from both sides. In 1972 Ingush intelligentsia prepared a lengthy text addressed to the Soviet Government (Gadziev, Kushtov, Pliev, Bazorkin, 1972). The authors expressed their dissatisfaction about the position of Ingushetia held among the Soviet Republics. In the letter is was said that the Ingush people were the victims of a conspiracy prepared by the nationalistic Ossetians, who skillfully utilized their connections in the communist party to acquire control first of Vladikavkaz and later of the Prigorodny region. It was argued that the efforts of the Ossetian elites not only created political

${ }^{2}$ Nikita Krushchev - First Secretary of the Central Committee of the Communist Party of the Soviet Union 1953-1964. 
tensions vis-à-vis Ingushetia, but simultaneously planted the seeds of hatred among the ordinary Ossetians.

The letter did not stay unnoticed on the Ossetian side. A harsh interchange of critical publications had significantly worsened the situation. In 1973, a mass Ingush demonstration in Grozny demanded restoration of Prigorodny in a constituency of Ingushetia. Many Chechens had joined the rally to express their solidarity (Fuller, 2008). Despite the joint meeting of the Regional Committees of both Autonomous regions in 1982, the territorial issue was not settled. Quite to the contrary, the Council of Ministers of the USSR passed a discriminatory Resolution on Limiting Registration in the Prigorodny District (March 5, 1982). The resolution banned the Ingush from registering in the region and denied them rights to acquire property (OssetianIngush Conflict, 2004).

During the Perestroika period, the communist government had been slowly losing grip on the events in the Caucasus. After the USSR collapsed, it had become evident that the transitional government in Russia was not prepared to deal with the waves of ethnic nationalism. Ekaterina Sokirianskaia has pointed out four factors that created conditions for the conflict in Prigorodny:

a) "The nationalization" of politics in the region;

b) The power struggle between the leadership of the USSR and the leadership of the Russian Federation;

c) The inflow of refugees from Georgia;

d) The emergence of free market of arms (Sokirianskaia, 2005/2006: 8).

The process of ethnic-national self-determination had created the context of the major political events in the early 90s Caucasus. Ethnic groups tried to establish themselves in a new political setting. Those people, who had the stronger fortitude to gain independence, were actively confronting the Russian Federation. However, others, like the Ingush, hoped that a new order in Russia would defy the Soviet past and help them to solve the problems. $92.5 \%$ of Ingush who voted (100,000 people) favored the formation of the Ingush Republic within the RSFSR, the return of the Prigorodny region and the part of Vladikavkaz on the right bank of the Terek River. The question was formulated as such: "Do you favor the creation of an Ingush Republic in the RSFSR along with the return of the illegally seized Ingush land and with the capital in the city of Vladikavkaz?" (Tishkov, 1997: 171).

The hope was revived during the presidential pre-election campaign, when Boris Yeltsin supported the claim of the Ingush Republic to re-acquire control of the Prigorodny region (Rezvani, 2015: 194). The Ossetian officials had reacted with establishing a state of emergency on the territory of Prigorodny.

On April, 26, 1991, the Russian Soviet Federal Social Republic's Supreme Soviet (ВерховныйСове́т; VerkhóvnyjSovét) passed the Law on the Rehabilitation of the Oppressed Peoples, intended to restore the territories within the pre-1944 boundaries (Gendron, 2009: 336). The regulation was greeted positively not only by the referents, but also by the liberal-democrats in Russia. However, the lack of clarity in technical details was causing some worries; the signed document did not provide a timeframe of implementation, neither did it explain the mechanisms of achieving the intended goals. As the first practical step, Russia planned the bilateral meeting. The aim of the meeting 
was to negotiate the terms of executing the law. The North Ossetian side decided not to participate and the effort went in vein.

The absence of the North Ossetian party was not a simple act of disobedience. It was a message that made the officials in the Kremlin realize that they could lose an important ally. It was apparent that the weakened government could not afford to further jeopardize the position in the Northern Caucasus. The Ossetians were not in an easy situation either; a large stream of migrants from Georgia was a cause for serious concern. Firstly, the locals in the North acknowledged that the massive immigration could cause social problems; secondly, as in support of the Southerners, the Kremlin remained largely silent, people in Vladikavkaz started thinking that the new Russian state would not support their cause anymore. During his visit in North Ossetia on March 24, 1991, Boris Yeltsin had visited a resort Nart, a settlement with ethnic Ossetian refugees who had fled from Georgia. The North Ossetian political elite did not miss the chance to complain about the problems with the Ingush; they expressed a great disappointment about Russia's lukewarm attitude towards the Ossetian mistreatment in Georgia. The same day B. Yetsin met Georgian president Z. Gamsakhurdia in Kazbegi. For the Vladikavkaz, the meeting did not look promising. B. Yeltsin was running in elections against the Soviet establishment and Z. Gamsakhurdia appeared to be the right man to support ${ }^{3}$ (Mejriev, 2016: 56).

Simultaneously, Chechnya, a brotherly state of Ingushetia, was gaining strength. The Ossetians were afraid that the Ingush could attack them at any possible moment. These fears had some roots in legislation. On March 31, 1992, the former Soviet Autonomous Republics signed the Union Treaty with Russia. The treaty "provided the legal basis for the coexistence of regions and republics of the Russian Federation and stipulated that the borders of the constituent parts of the federation could not be amended without popular consent" (Kasaev, 1995). Ingushetia was not among the signatories, and therefore was "free of any constitutional or legal constraint in pressing their claims for control over the Prigorodny region" (Ibid.: 3).

Subsequently, both Ingushetia and North Ossetia started organizing their armed forces. If the first was doing it largely through their own resources, the latter was getting a significant help from the Russian Federation (Albogachieva, 2012: 50). ${ }^{4}$ The Ingush elite acknowledged that the Law on the Rehabilitation of the Oppressed Peopleswas destined to remain on the paper. Nevertheless, they did not expect that in case of conflict, Moscow would openly support the Ossetian side.

The pivotal event took place on October 1992 with the decision taken by representative governing authorities of Ingushetia; the conclusion was a de facto call to establish a pre-deportation setting by force. This call was resonating among the Ingush as they heard the reports about "incidents of organized harassment against Ingushetian inhabitants of North Ossetia by their North Ossetian neighbors and North Ossetian police" (Kasaev, 1995: 4).

The armed conflict started on October 31. The North Ossetians argued that the Ingush initiated the violence. The Ingush, to the contrary, maintained that they fired

\footnotetext{
${ }^{3}$ Zviad Gamsakhurdia, $1^{\text {st }}$ president of Georgia was a former Soviet dissident.

${ }^{4}$ The Ossetians received the huge amount of the automatic weapons, missiles and vehicles from the Russian Federation.
} 
in self-defense. The Russian peacekeeping force deployed on the border was clearly supporting the Ossetians. Their task was to ensure that the Prigorodny region remained within the boundaries of North Ossetia (Hunter, 2006: 121). The Russian troops were already in place, when the conflict burst out, but they did not take any significant measures to stop it (Rezvani, 2010: 425). As the result of the conflict, over 60,000 Ingush living in North Ossetia forcibly fled to the neighboring autonomous republics (Dzutsati, 2011).

\section{POST CONFLICT SITUATION}

The conflict had a serious social impact on the populations. However, the political mood was much better on the winning Ossetian side than on the opposing Ingushetia. The heroic narratives and the stories about the Ingush betrayal dominated in Vladikavkaz. The politicians made sure that the average Ossetian citizen shared the discourse according to which, the ethnic cleansing of the Ingush population was a preemptive action against the plot of the Ingush elite to forcefully re-gain control over Prigorodny. The common Ossetian storylines suggested that the locally resided Ingush were directly involved with the plans written in Nazran and Grozny. It was a full-fledged dehumanization of the enemy at every societal level, starting from the political elites ending with the ordinary citizens.

The situation in Ingushetia was much more difficult. Together with obvious material loss, the defeat in war became a grim cultural abashment for the Ingush, to whom the Prigorodny region had a historical significance; a village Tarskoe - also known as Angusht, is identified as a basis for the Russian ethnonym Ingush (Nichols, 1997). ${ }^{5}$ The people believe that by depriving them from their homes, the Ossetians took a part of their history as well.

The condition was hardened further, due to the role that the Russian Federation played in the developments. The Ingush ware convinced that Russia was on the opposite side in the conflict. The question was not solely how the Ingush would live under the same state with the Ossetians, but also, how would the common state treat them in the future. Mats Friberg has argued that "there is nothing innately ethnic" in ethnic conflicts, "rather, it is often the failure of governing structures to address fundamental needs, provide space for participation in decisions, and ensure an equitable distribution of resources and benefits that makes identification with a group so attractive and salient in a given setting" (in Lederach, 1997: 8). As we have observed above, the Ingush had been constantly mistreated by the 'governing structures' vis-à-vis the Ossetians. The self-awareness of the people was shaped in this context and the armed conflict had only sharpened the negative connotations.

The Russian leadership acknowledged that in order to gain stability in the region, it was important to start the process of reconciliation. The Ingush demands were clear: the central government had to create the conditions for bringing the refugees back home to Prigorodny. The task was not the simplest one for two reasons: First, the

\footnotetext{
5 The Ingush call themselves Ghalghaaj.
} 
Russian Federation was dealing with the ongoing crisis in Chechnya and the South Caucasus; therefore, it did not have the time nor the logistical resources to re-establish living conditions in Prigododny. Second, nobody had the illusion that the post-conflict societies could just forget the war and continue living together as if nothing happened. Figuring out the reconciliation procedures required time and effort.

Simultaneously, the High Council of North-Ossetia approved a statement about the "Impossibility of cohabitation of the Ossetians and the Ingush" (Luneev, 2005: 373). This was a clear signal that the officials in Vladikavkaz would oppose the return of the Ingush at any cost.

In the given condition, the Russian Federation had a clear list of tasks to accomplish: a) establishing an effective initial setting for securing peace in the region; b) regaining the trust of the Ingush by being a neutral third party in mediation; c) persuading the Ossetians to give up their hardline position against the return of the Ingush; d) creating indisputable territorial boundaries to avoid further conflicts.

\section{PROCESS OF RECONCILIATION}

After the formal cease-fire, the federal center had drafted numerous regulatory acts, decrees and resolutions. However, those documents did not stop the violence in various forms. We need to highlight the fact that the Russian government was dealing with several ongoing problems at that time. The Kremlin authorities were trying to re-gain influence in the South Caucasus by encouraging the separatist conflicts; simultaneously, the military operation in Chechnya required mobilizing most of their organizational resources. A hard transition from the Soviet system to the quasi-democratic governance was accompanied by severe economic complications. The new administration could hardly manage to maintain stability in the state. Considering these factors, it is not surprising that there was very limited progress in reconciling the parties in Prigorodny.

The Russian peacekeepers in Prigorodny made a hard-military line to avoid the large ethnic clashes, but the center was ineffective in dealing with the increasing crime. Criminal acts in the post-conflict society, even if they were not connected with the political situation, could acquire an ethnic significance. This was true between the Ingush and Ossetians; general crime (apolitical) was often interpreted as residual violence ${ }^{6}$ and this interpretation connoted to general hostility.

The governmental commissions had signed a large number of documents; the majority of which were not implemented. The minimalist policies of the federal center were employed to 'liquidate the consequences of the conflict' and it did not imply a full-scale process of reconciliation. The government planned the tasks to create living conditions for the internally displaced persons; the returning and reintegration of the Ingush seemed to be just on the papers (Sokirianskaia, 2005/2006: 12).

The immediate step of the Russian government was to establish a state of emergency, and put a "temporary administration" in charge of the Prigorodny region (decree

6 "Residual violence: Often a continuation of the conflict or tied to it, residual violence can include revenge attacks by one ethnic group on another or violence by splinter groups of a faction to the peace agreement" (see: Fedotov, Solomon, 2011). 
November 2,1992). Article 5 of the 1992 decree stated that the temporary government was to prevent armed conflict between the opposing sides. The same year, B. Yeltsin answered the request of the North Ossetian president and established a peculiar administrative arrangement; the issued decree "created a situation of dual power whereby local authorities would have to obey both their own government edicts and those of the Temporary Administration". This duality negatively affected the functioning of the administration (Laber, Denber, Robinson, 1996).

The new setting soon adopted the United Investigative - Operative Group (OSOG). The OSOG was created by the Russian Ministries of Internal Affairs, Security and Procuracy, to investigate the reasons of the conflict, and to unveil the crimes committed. Setting up the investigative group appeared to be a mere formality, but the initiative on its own had a broader meaning. The conflict is a sacral event for the winners - revisiting the past is an exercise of self-gratification. While for the losers, it is a constant reminder of the failure and injustice. A desacralisation of the past is a first step on the path of reconciliation. The parties have to agree at least on the broad picture that would include a set of meaningful facts. The truth commissions and third party investigations serve this purpose. The Russian authorities acknowledged the necessity to display a formal neutrality in the dialogue. The OSOG seemed to be a proper message directed primarily toward the Ingush, which believed that unveiling the pure facts would prove their rightness. The investigations did not have a meaningful result. The biggest problem for the group, as ascertained by the officials, was a "serious pressure and impediments both from the authorities of both republics as well as from their population" (Ibid.).

On March 20, 1993, the North Ossetian leader, AkhsarbekGalazov, and his Ingush counterpart, Ruslan Aushev, signed the Kislovodsk agreement. The agreement included a multifaceted mechanism to regulate the security issues and proposed the ways of the IDP return. The follow-up conference, chaired by Yeltsin noted down a general vision for the future arrangements according to which the Ingush side had to abandon their territorial claims on Prigorodny and, as an exchange, the Ossetians would withdraw their decision about the impossibility of cohabitation with the Ingush. ${ }^{7}$ Consequently, on December 13, 1993, President Yeltsin issued the Decree N2131, ordering the return of Ingush people to the four villages of the Prigorodny region.

On June 24, 1994, the temporary administration and both parties signed the Beslan agreement. The agreement complemented the Decree N2131, the Emergency Rule Decree N1112 and the Kislovodsk accords. The document planned the return of the Ingush IDPs in a two-stage process. During the preparatory stage, the officials had to organize the lists of those people who were documented residents of Prigorodny. The stage also encompassed rebuilding the essential infrastructures for life. The second stage would have started a process of return of the persons whose houses were intact. The governments took responsibility to provide temporary housing for those, whose households were destroyed. The agreement indicated that the returnees had to recognize the territorial integrity of North Ossetia (Memorial, 1994).

The Beslan agreement was not perfect. However, it was the first real step towards the return of the displaced persons. The Russian government was not fully able to ac-

\footnotetext{
${ }^{7}$ This vision was enacted only in 2009.
} 
complish the logistical tasks described in the document. This meant that the Ingush were returning to live in extreme poverty among the hostile Ossetians. Nevertheless, the majority of IDPs did not have much choice; many of them had found a temporary habitat in Grozny, which was a center of the armed conflict.

Around $85 \%$ of refugees of 60,000 voluntarily returned home. During the process, the Ossetians had been using every means to create obstacles for the Ingush; regular provocations directed from the administrative centers made an uneasy situation for the returnees. There were the outbursts of the protests against the Ingush; the Ossetian authorities clarified that the demonstrations were spontaneous, but the evidence suggests the opposite (Sokirianskaia, 2005/2006: 39). The provocations could be considered minor disturbances in comparison to the administrative difficulties created for the Ingush. In 1999, the Ossetian government approved a discriminatory social package for those ethnic Ossetians who suffered from the Ingush aggression. This policy not only proclaimed the Ingush as aggressors but also disproportionally distributed governmental money. Meanwhile, the Ingush struggled to use even basic public services. For instance, in those villages where the Ossetians and the Ingush lived together, the separated communities, libraries, administrative buildings and social clubs were situated in the Ossetian neighborhoods (Ibid.: 34).

Another serious problem was finding a path for the de-militarization of the Ossetian fighters. After the war, they were incorporated into the security services. Therefore, cases of mistreatment of the Ingush population were quite common. The situation had been significantly improved when Alexander Dzasokhov became a chief executive of north Ossetia. He managed to create the joint security units. The major achievement of the policy was that "by 2004 the level of ethnically based violence had been reduced to minimum" (Ibid.).

After the second war in Chechnya, several terrorist groups were formed in the North Caucasus region. In the beginning, these groups had political goals, especially the groups that were founded by the Chechen militaries. However, later, the most influential clusters acquired a religious direction. Ingushetia became a hub for the multiethnic terrorists; the local government was powerless to deal with this problem.

The Beslan terrorist attack was a major event that changed the dynamics of the region. First, "the brutality of the attack and specific targeting of children destroyed most of the Russian public's sympathy for Chechnya's independence movement" (Banovac, Patterson, 2007: 5). Second, the attack created a necessity to re-activate a dialogue between the Ingush and Ossetians.

Some Ossetian groups tried to show the terrorist attack in the context of the Prigorodny conflict. However, the officials did everything possible to avoid creating an ethnic narrative. During the developments, the authorities strongly maintained that the group of terrorists was multiethnic and their primary target was not the Ossetian people, but the Russian state. Nevertheless, there were some statements that underlined the fact that a significant number of the attackers were ethnic Ingush; the immediate narrative generated around the act was fearsome; the Ossetians "assumed they were under attack because they were Ossetians; because they were Christians and because their regional republic had remained loyal to the Russian government" (Phillips, in: Ó Tuathail, 2009: 12). 
There were tendencies to generalize the actions of a few Ingush terrorists on the entire Ingush population. However, neither the terrorists, nor the Kremlin wanted to sharpen this discursive line. The Russian government was willing to put the blame on Chechens for two reasons: first, if the attack was organized by the Chechens, it would de-legitimize their ethnic struggle for independence; second, this would shift the blame from the Ingush and therefore, help to avoid complications in Prigorodny (Ó Tuathail, 2009: 8-11). The theories about the Ingush conspiracy against the Ossetians became obsolete after the leading terrorist, Shamil Basayev, claimed responsibility for the attack and portrayed the act as a response to Russia's aggression in Chechnya. ${ }^{8}$

Several organizations have a clear anti-Ingush stance; Mothers of Beslan and Voice of Beslan, consist of individuals whose families suffered the tragedy. The personal trauma makes their position understandable (Shevchenko, 2011). The consequent research has shown that the majority of Ossetians do not see the connection between the terrorist attack and the Prigorodny conflict. Instead, most citizens believed that the attack had its roots in global terrorism or was inspired by the enemies of the Russian state (Ó Tuathail, 2009: 11).

The CSIS study of 2006 unveiled a few important trends in Ossetian-Ingush relations. The majority of Ossetians did not trust the Ingush; a significant number of respondents had negative attitudes toward Islam. The Ossetians acknowledged that the Ingush were the most mistreated ethnic group in North Ossetia ${ }^{9}$ (Gerber, Mendelson, 2006: 50).

The historical agreement took place in 2009. The Head of Ingushetia Yunus-bek Yevkurov and Taymuraz Mamsurov signed a document, which was an outcome of a mutual political compromise. The leaders have jeopardized their political careers, as the decision was highly unpopular in both societies. The agreement re-visitedthe recommendations drawn by the conference of 1993 noted earlier in this chapter. The Ossetian side was taking responsibility for full-scale re-integration of the returnees in Prigododny based on equal rights with the Ossetian citizens. In return, Ingushetia recognized the conflict territory as being in Ossetian jurisdiction. Yunus-bek Yevkurov pointed out that the decision had a primary aim - facilitating the life of the Ingush population. His position was simple: if the Ingush return home, the legal status of the villages was not that important. The Ossetian officials saw the agreement as a possibility to reestablish relations with neighbors. After signing the document, political discourse has changed; the politicians from both sides were more cautious in expressions, they tried to re-visit the conflict by portraying it as a result of political mistakes. The war, in a new context, was described as a common tragedy. Despite the initial skepticism, the policy of cooperation started to work slowly but steadily. The problems still exist; however, they are more connected with the negative influence of some societal groups. Political Expert Maksim Shevchenko has pointed out in an interview that people could have a good chance of reconciliation, if some public intellectuals changed their hostile positions (Shevchenko, 2011). The negative influence of the elders and other influential figures has been evident throughout the dialogues. The round tables organized by the governments often worsened the tensions; the people that sat facing each other

\footnotetext{
${ }^{8}$ This claim was rather vague, as there were only few Chechens among the terrorists.
}

${ }^{9}$ Mistreated by the authorities. 
had been exchanging hostile messages for even decades before the war and after, were actively engaged in the conflict. (Sokirianskaia, 2005/2006: 39)

$$
* * *
$$

The processes have shown that the Russian state did not have a self-contained aim to encourage or support the Ossetians in the conflict. However, the political context in the newly emerged Russian state and problematic developments in the Caucasus region determined the role of the Kremlin in the processes. Based on the key findings of this article we can identify the phases of the process:

A) Pre-conflict phase (Soviet times): the discursive struggle between the sides was accompanied by the Soviet Authorities' indifferent attitudes. Nevertheless, the officials were inclined to support the Ossetian side. The Ingush requests to restore a pre-deportation status quo stayed largely unnoticed.

B) Conflict phase (the early 90s): Ossetian provocations and pre-supposed Russian neutrality encouraged the Ingush to think about taking control of Prigorodny by military means. However, the escalation of the conflict took place due to the armed measures used by the Ossetian side. The Russian troops did not upset the Ossetian allies and created conditions in which the Ingush population left the Prigorodny district.

C) Early post-conflict: Yeltsin's government had significant political problems. Therefore, every effort to start a dialogue initiated by the center was largely ineffective. However, the sides managed to keep a relatively peaceful setting.

D) Process of reconciliation (mid 90s): The Beslan agreement was the first real step towards reconciliation. The IDPs started to return, the problems were to create basic living conditions for the returnees and agreeing on the legal status of Prigorodny.

E) Current State (after the year 2000): the agreement reached in 2009 drew the final lines between the Ossetian-Ingush relations. Ingushetia agreed to give up Prigorodny in exchange for the full return of the IDPs. The infrastructural problems together with some complications at a societal level remain. The Federal government largely plays a positive role in the processes.

\section{BIBLIOGRAPHY}

Albogachieva M. (2012), The Ossetian and Ingush Conflict: Causes and Echoes of the Tragedy of the Fall of 1992, "The Caucasus \& Globalization", Vol. 6 (4).

Banovac S., Patterson C. (2007), Terror at Beslan: A Chronicle of On-going Tragedy and a Government's Failed Response. Anatomy of a Terrorist Attack, The Ridgway Center, Pittsburgh.

Dzutsati V. (2011), Conflict Said to be Resolved, Continues to Flare between Ossetians and Ingush, "Eurasia Daily Monitor", No. 8 (210).

Fedotov Y., Solomon R. (2011), Criminal justice reform in post-conflict States A guide for practitioners, United States Institute of Peace, New York.

Fuller L. (2008), Russia: Ingush Commemorate Landmark Protest, Radio Free Europe Radio Liberty, http://www.rferl.org/content/article/1079373.html (1.03.2016). 
Gadziev A., Kushtov A., Pliev S., Bazorkin I. (1972), Letter to the Central Committee of the CPSU on the fate of the Ingush people, Press release, https:/ghalghay.com/2010/01/16/письмо-вцк-кпсс-о-судьбе-ингушского-на/ [RUS].

Gendron R. (2009), Alternative Dispute Resolution in the North Caucasus, "Caucasian Review of International Affairs", Vol. 3 (4), Autumn.

Gerber T. P., Mendelson S. E. (2006), Cauldron of Terrorism or Bowl of Kasha? What Survey Data Say About the North Caucasus, CSIS.

Hunter S. (2006), Borders, Conflict, and Security in the Caucasus: The Legacy of the Past, "SAIS Review of International Affairs", Vol. 26 (1), DOI: 10.1353/sais.2006.0011.

Kasaev A. C. (1995), U.S. and Russian Policymaking with Respect to the Use of Force, Rand Corporation, http://www.rand.org/pubs/conf_proceedings/CF129/CF-129-chapter1.html (2.03.2016).

Laber J., Denber R., Robinson S. (1996), Russia the Ingush-Ossetian Conflict in the Prigorodnyi Region, Human Rights Watch, New York.

Lederach J. P. (1997), Building peace: sustainable reconciliation in divided societies, United States Institute of Peace Press, Washington, D.C.

Luneev V. (2005), Crime of the XX century, global regional and Russian trends, Преступность ХХ века: мировые, региональные и российские тенденции, Moscow.

Mejriev K. (2016), Осетино-Ингушский Конфликт В Контексте Современной Геополитики Pоссии, LomonosovMoscowStateUniversity, Doctoralthesis, Moscow.

Memorial. Two years after the war: Problem of displaced persons in the zone of Ossetian-Ingush conflict (1994), Memorial Human Rights Center, http://www.memo.ru/eng/memhrc/ persec/2yaw/2yaw1.shtml (21.01.2017).

Nichols J. (1997), The Ingush (with notes on the Chechen): Background information, University of California, Berkeley.

Ossetian-Ingush Conflict (2004), Caucasian Knot, http://eng.kavkaz-uzel.ru/articles/2187/ (2.03.2016).

Ó Tuathail G. (2009), Placing blame: Making sense of Beslan, "Political Geography", Vol. 28 (1), DOI: http://dx.doi.org/10.1016/j.polgeo.2009.01.007.

Pokalova E. (2015), Chechnya's Terrorist Network; Evolution of Terrorism in Russia's North Caucasus, ABC-CLIO, LLC.

Rezvani B. (2010), The Ossetian-Ingush Confrontation: Explaining a Horizontal Conflict, "Iran $\&$ the Caucasus", Vol. 14 (2).

Rezvani B. (2015), Conflict and Peace in Central Asia, Towards Explanations and Understandings, Boston.

Shevchenko M. (2011), in: Osobaia Mnenie, (ed.) O. Zuravleva, Echo Moskvy, Moscow, http://echo. msk.ru/programs/personalno/769882-echo/ (21.01.2017).

Sokirianskaia E. (2005/2006), Getting Back Home? Towards Sustainable Return of Ingush Forced Migrants and Lasting Peace in Prigorodny District of North Ossetia, Open Society Institute, Central European University, http://pdc.ceu.hu/archive/00002841/01/sokirianskaia06.pdf (7.03.2016).

Telegraph (2001), 1944-1957: Deportation and Exile Retrieved March 1, 2016, “The Telegraph", http://www.telegraph.co.uk/news/1399561/1944-1957-Deportation-and-exile.html.

Tishkov V. (1997), Ethnicity, Nationalism and Conflict in and After the Soviet Union, The Mind a Flame, United Nations Research Institute for Social Development, New York. 


\begin{abstract}
The conflict, which took place between the Ossetian and Ingush ethnic groups, had severe political consequences. The process of reconciliation has been ongoing for over two decades, but the results are still questionable. The Russian federation played a decisive role in the processes. The authorities of the Russian Federation mistreated the Ingush and supported the Ossetians; this condition encouraged the conflict and served as an obstacle in mediating the dialogue. The article examines the scale and effectiveness of intergovernmental agreements by analyzing the relations between the Ossetian, Ingushetian and Russian authorities. The research proposes a general set of political factors that have been shaping the societal attitudes of the conflicting parties. The work attempted to some key reasons which determined the Kremlin's position(s) in the conflict and reconciliation.
\end{abstract}

Keywords: Conflict, Ingushetia, Ossetia, Prigorodny, Russia

\title{
KONFLIKT I POJEDNANIE W REGIONIE PRIGORODNY
}

\section{STRESZCZENIE}

Konflikt mający miejsce pomiędzy Osetyńczykami a Inguszami niósł za sobą wiele politycznych konsekwencji. Proces pojednania trwa od ponad dwóch dekad, niestety same rezultaty jawią się wątpliwymi. Federacja Rosyjska odgrywa decydującą rolę w samym procesie, władze Federacji Rosyjskiej nie doceniły siły Inguszy i poparły Osetyńczyków. Argument ten przyczynił się do eskalacji konfliktu i funkcjonował jako główne ognisko zapalne podczas mediacji.

Slowa kluczowe: konflikt, Inguszetia, Osetia, Prigorodny, Rosja 
